\title{
FOREIGN-BODY REACTIONS TO FRACTURE FIXATION IMPLANTS OF BIODEGRADABLE SYNTHETIC POLYMERS
}

\author{
O. BÖSTMAN, E. HIRVENSALO, J. MÄKINEN, P. ROKKANEN
}

From the University Central Hospital, Helsinki

\begin{abstract}
Biodegradable rods of polyglycolide or lactide-glycolide copolymer were used in the internal fixation of a variety of fractures and osteotomies in $\mathbf{5 1 6}$ patients. A clinically manifest foreign-body reaction occurred in 41 patients (7.9\%), producing a fluctuant swelling at the implantation site after an average of 12 weeks. Spontaneous sinus formation or surgical drainage yielded a sterile exudate containing liquid remnants of the degrading implants. After prompt drainage this discharge subsided within three weeks.

Histological examination showed a typical nonspecific foreign-body reaction with abundant giant cells both in patients with the reaction and in some patients with an uneventful clinical course. The factors determining the nature of the reaction were probably related to the local capacity of the tissues to clear the polymeric debris. The reactions did not influence the clinical or radiographic results, but recognition of the incidence and the features of the reaction is necessary in view of the increasing use of such implants.
\end{abstract}

After extensive research, devices for the internal fixation of fractures made of the biodegradable synthetic alphahydroxy polyesters polyglycolide, lactide-glycolide copolymer, polylactide, and polydioxanone have been in clinical use for about five years (Rokkanen et al 1985; Haas 1986; Böstman et al 1987, 1989; Eitenmüller, Entenmann and Muhr 1988; Hirvensalo et al 1988a, b; Partio et al 1988; Rokkanen et al 1988; Rozema et al 1988). The materials have been used as rods, pins and screws in several thousand patients. The overall results have so far been favourable, but about $6 \%$ of patients have developed a tissue reaction at the implantation site, two to four months after the operation (Böstman et al 1987, 1989; Hirvensalo et al 1988a, b; Rokkanen et al 1988 ) and often required surgical drainage. Our present study aims to elucidate the nature of these reactions.

\section{MATERIAL AND METHODS}

From November 1984 a prospective study was made of all patients treated at the authors' department with

O. Böstman, MD, Orthopaedic Surgeon

E. Hirvensalo, MD, Orthopaedic Surgeon

J. Mäkinen, MD, Senior Lecturer in Pathology

P. Rokkanen, MD, Professor and Director

Department of Orthopaedics and Traumatology, University Central

Hospital, Topeliuksenk 5, SF-00260 Helsinki, Finland.

Correspondence should be sent to $\mathrm{Dr} \mathrm{O}$. Böstman at Tiirasaarentie 11 A 3, SF-00200 Helsinki, Finland.

(C) 1990 British Editorial Society of Bone and Joint Surgery $0301-620 X / 90 / 4144 \$ 2.00$

J Bone Joint Surg [ Br] 1990; 72-B: 592-6. biodegradable rods made of lactide-glycolide copolymer (polyglactin 910) or, from October 1985, of polyglycolide. The implants were cylindrical, from 1.5 to $4.5 \mathrm{~mm}$ in diameter and from 20 to $70 \mathrm{~mm}$ in length (Törmälä et al 1988). Both these alpha-hydroxy polyesters are degraded via glycolic and lactic acids into completely absorbable and metabolisable compounds within 120 days.

By January 1988, 516 patients had been treated (Table I), 40 with lactide-glycolide copolymer and 476 with polyglycolide rods. All the rods had been placed intra-osseously (Böstman et al 1989) by tapping them into predrilled channels through the fracture or osteotomy

Table I. Frequency of clinical foreign-body reactions in 516 patients having biodegradable implants for internal fixation

\begin{tabular}{|c|c|c|c|}
\hline \multirow[b]{2}{*}{ Fracture or osteotomy } & \multirow{2}{*}{$\begin{array}{l}\text { Number of } \\
\text { patients }\end{array}$} & \multicolumn{2}{|c|}{ Patients with reactior } \\
\hline & & Number & Per cent \\
\hline $\begin{array}{l}\text { Coracoid osteotomy for recurrent } \\
\text { dislocation of the shoulder }\end{array}$ & 13 & 1 & 8 \\
\hline Intra-articular fracture at the elbow & 43 & 5 & 12 \\
\hline $\begin{array}{l}\text { Fracture of distal radius, metacarpals } \\
\text { or phalanges }\end{array}$ & 16 & 2 & 13 \\
\hline $\begin{array}{l}\text { Scaphoid nonunion, with } \\
\text { simultaneous bone grafting }\end{array}$ & 20 & 5 & 25 \\
\hline Intra-articular fracture at the knee & 13 & 2 & 15 \\
\hline $\begin{array}{l}\text { Hauser's operation for recurrent } \\
\text { dislocation of the patella }\end{array}$ & 11 & 1 & 9 \\
\hline Malleolar fracture of the ankle & 338 & 22 & 7 \\
\hline Chevron osteotomy for hallux valgus & 62 & 3 & 5 \\
\hline
\end{tabular}


surfaces (Fig. 1). The volume of the implanted material varied from $63 \mathrm{~mm}^{3}$, (one $2 \times 20 \mathrm{~mm}$ rod for scaphoid nonunion) up to $3000 \mathrm{~mm}^{3}$, (several 3.2 or $4.5 \times 50$ or $70 \mathrm{~mm}$ rods for ankle fractures).

In 460 cases $(89.1 \%)$, the clinical course was uneventful. Six patients $(1.2 \%)$ had re-operation for failure of fixation, and nine $(1.7 \%)$ had bacterial wound infections.
The highest incidence, $25 \%$, was after fixation of a scaphoid nonunion (Table I). There was no difference in incidence between lactide-glycolide copolymer $(7.5 \%)$ and polyglycolide $(8.0 \%)$. In bimalleolar ankle fractures the reaction occurred on both the lateral and the medial side in eight of 11 patients and on the lateral side only in three.

Nine patients already had a sinus when they were

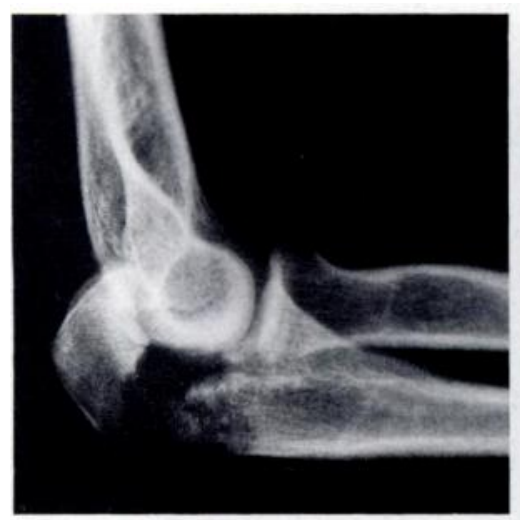

Fig. la

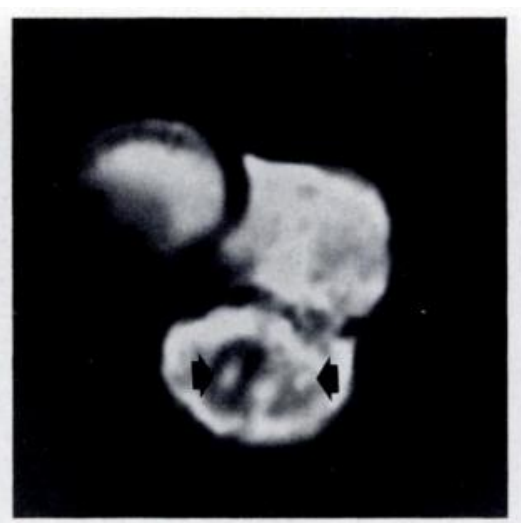

Fig. 1b

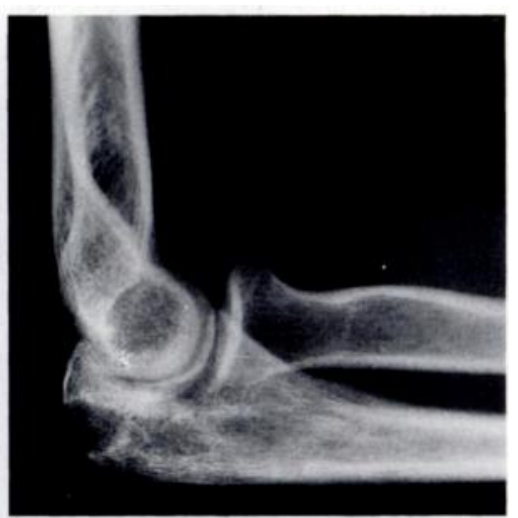

Fig. 1c

Figure 1a - Displaced fracture of the olecranon. Figure 1b-CT scan at 12 weeks after open reduction and internal fixation with polyglycolide rods. The degrading implants in the ulna (arrows) have surrounding radiolucent areas, but the clinical course was uneventful. Figure 1c - Two years later there is anatomical union of the fracture, but a residual radiolucent area is seen at the tip of the olecranon.

In 41 patients $(7.9 \%)$, with no previous complications, a painful swelling developed at the operation site after two to four months. This non-bacterial, inflammatory response was studied in all cases clinically, radiographically and by laboratory tests for a minimum followup of 18 months.

Surgical drainage or debridement allowed the collection of adequate specimens for histopathological examination from the implant channel in 11 patients. Specimens were also taken for comparison from five patients with no macroscopic signs of an inflammatory reaction at operations for mechanical failure of fixation. The biopsy specimens were fixed in formaldehyde, and sections were stained with haematoxylin and eosin. Polarising microscopy was used to demonstrate birefringent material.

\section{RESULTS}

Of the 41 patients, 22 were women and 19 men; their ages ranged from 18 to 77 years (mean 38.8). The tissue response had always started as a suddenly emerging, painful, red, fluctuant swelling, 5 to $10 \mathrm{~mm}$ in diameter, in a normally healed incision scar. The mean interval between the operation and the reaction was 81 days (range 50 to 113). first seen. In others, drainage of the exudate by needle aspiration or by incision under local anaesthesia yielded liquid remnants of the implant. Such minor procedures were sufficient to allow the reaction to settle in 30 cases; 11 patients required admission and a more extensive debridement. Wound drainage ceased, on average, by five weeks, but continued for up to four months in two cases. In the 17 patients who had sought attention within two days of the first symptoms and had immediate drainage, the discharge ceased in less than three weeks.

The fractures and osteotomies fixed by the implants had all united before the inflammatory response started, and we saw no uniform radiographic changes attributable to the reaction. CT scans made at 12 weeks in some cases showed increased radiolucency around the degrading implants both in patients with an inflammatory reaction and in those with an uneventful course (Fig. 1b).

Laboratory data. Two or more bacterial specimens were obtained from the exudate of each patient. No bacterial growth could be demonstrated on aerobic or anaerobic culture. The mean of the highest erythrocyte sedimentation rate (normal less than 11) was $39 \mathrm{~mm} / \mathrm{h}$ (range 9 to 112) and the mean of the highest serum concentration of C-reactive protein (normal value less than 10) was $34 \mathrm{mg}$ / 1 (range 13 to 204).

Histology. There were common features in all the 
histological specimens, both from patients with clinically manifest inflammatory reactions and those without. Often an abundant collection of macrophages and multinucleated foreign-body giant cells were phagocytosing the broken-down implant material (Fig. 2) and there was an inflammatory response by neutrophilic polymorphonuclear leucocytes and small lymphocytes (Fig. 3). The polymeric debris was identified by its birefringence under polarised light. The histology was exactly the same in specimens obtained from patients with or without a macroscopic reaction.
1986; Hollinger and Battistone 1986; Eitenmüller et al 1987). Although thousands of animal experiments have been performed, only Greve and Holste (1985) have recorded a macroscopic inflammatory tissue reaction in a test animal. However, because of the design of many of the experiments, few animals lived long enough for a reaction to become manifest, and inflammatory reactions may have been ignored as supposedly trivial bacterial infections. No immunologically mediated reactions against polyglycolide (Dexon) or lactide-glycolide copolymer (Vicryl) as suture materials have been reported.

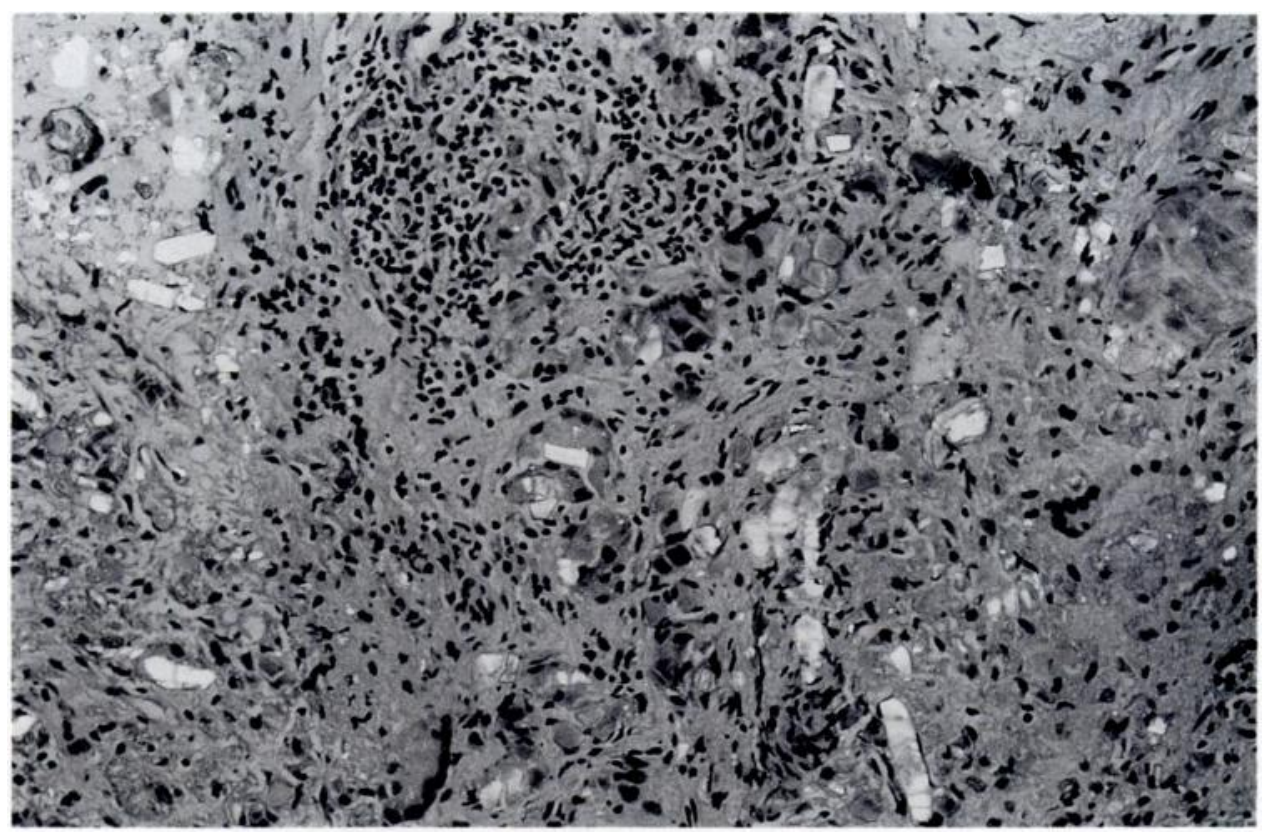

Fig. 2

Histological specimen from a patient with an inflammatory reaction 10 weeks after fixation of a trimalleolar fracture. Foreign-body giant cells are phagocytosing birefringent polymeric debris within the fibroconnective tissue (Polarised light, haematoxylin and eosin $\times 90$ ).

As would be expected, the histological characteristics were affected by the time since implantation. Specimens obtained after two to five months showed an unmistakably active foreign-body reaction, while in biopsies obtained at six to 12 months the reaction had settled though polymeric debris was still visible. In two patients, additional specimens taken at 18 months showed no implant material.

\section{DISCUSSION}

The histological findings were typical of a nonspecific foreign-body reaction. In animal experiments, several investigators have considered that the mild reaction elicited by biodegradable polymers was a normal biological response to the absorption of such implants (Cutright and Hunsuck 1972; Vert et al 1984; Gay and Bucher 1985; Howard, McKibbin and Ráliš 1985; Claes et al
Despite considerable clinical experience with biodegradable fracture fixation devices, very few large follow-up series have been reported. The clinically significant reactions we have studied, probably represent one end of a continuous spectrum of biological responses, which were of subclinical intensity in the majority of the patients. This concept is supported by the histological reaction seen in patients with no clinical symptoms.

The time to degradation of polyglycolide or lactideglycolide copolymer implants is estimated to be from 90 to 120 days (Vert et al 1984; Hollinger and Battistone 1986), so the average of 81 days before the appearance of the clinical signs of a reaction corresponds well to the liquefaction of the implant. The radiolucent areas seen around the implant channels on CT scans at this time, probably represent liquid polymeric debris. Some implant material remains in situ even after depolymerisation: in the rat tibia, about $70 \%$ of the implanted activity 


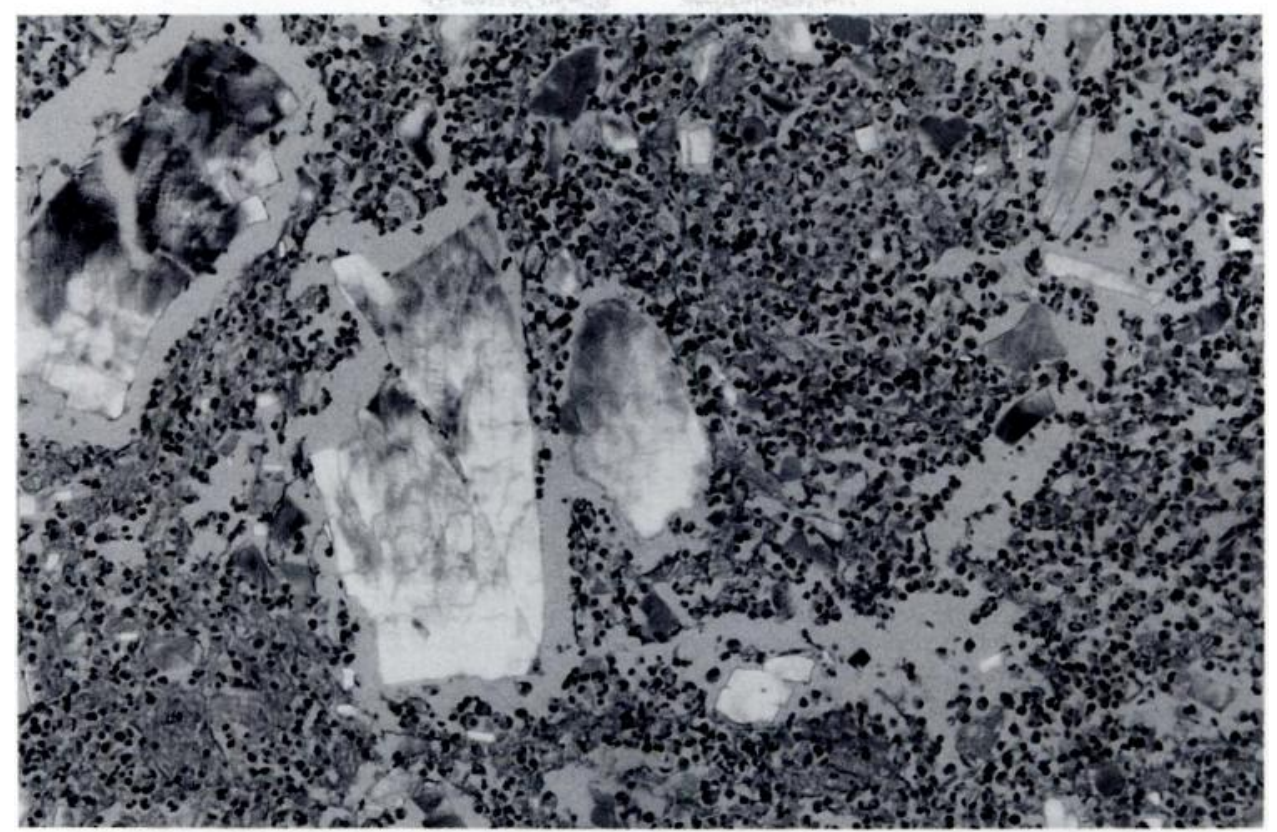

Fig. 3

Histological specimen from a patient re-operated at 13 weeks for failure of fixation of a lateral malleolar fracture. Birefringent fragments of the degrading polyglycolide rod are seen surrounded by masses of neutrophilic polymorphonuclear leucocytes. There had been no clinical signs of an inflammatory reaction (Polarised light, haematoxylin and eosin $\times 150$ ).

remained at the site three months after pellets of carbon14 and tritium-labelled polyglycolide had been implanted (Miller, Brady and Cutright 1977). The formation of such liquid polymeric debris must make great demands on the clearing capacity of a relatively compact tissue like cancellous bone, so the factors determining the development of a clinically manifest reaction would seem to be the local tissue tolerance and transport potential. The high incidence of reactions in scaphoid nonunions was probably due to the poor vascular supply of the bone.

The final functional and radiographic result was not influenced by the clinical reactions, but prompt surgical drainage seems to be mandatory when a reaction is seen. It is unlikely that it will be possible to predict the risk of such a reaction in an individual patient.
Biocompatibility of a material or implant has been defined as the ability to perform with an appropriate host response in a specific application (Williams 1988). Our findings, in our opinion, do not contradict the wellestablished basic biocompatibility of polyglycolide and lactide-glycolide copolymer, though some modifications in previous concepts are indicated. Future work will show whether implants with a longer degradation time, like those made of polylactide, will induce less manifest foreign-body reactions in larger scale clinical use.

Although none of the authors have received or will receive benefits for personal or professional use from a commercial party related directly or indirectly to the subject of this article, benefits have been or will be received but are directed solely to a research fund, foundation, educational institution, or other non-profit institution with which one or more of the authors is associated.

\section{REFERENCES}

Böstman O, Vainionpää S, Hirvensalo E, et al. Biodegradable internal fixation for malleolar fractures: a prospective randomised trial. $J$ Bone Joint Surg [ Br] 1987; 69-B:615-9.

Böstman O, Hirvensalo E, Vainionpää S, et al. Ankle fractures treated using biodegradable internal fixation. Clin Orthop 1989; 138: 195-203.

Claes L, Burri C, Kiefer H, Mutschler W. Resorbierbare Implantate zur Refixierung von osteochondralen Fragmenten in Gelenflächen. Aktuel Traumatol 1986; 16:74-7. (Eng. abstr.)

Cutright DE, Hunsuck EE. The repair of fractures of the orbital floor using biodegradable polylactic acid. Oral Surg 1972; 33:28-34.
Eitenmüller J, Gerlach KL, Schmickal T, Muhr G. Semirigide Plattenosteosynthesen unter Verwendung absorbierbarer Polymere als temporäre Implantate. II. Tierexperimentelle Untersuchungen. Chirurg 1987; 58:831-9. (Eng. abstr.)

Eitenmüller J, Entenmann H, Muhr G. Treatment of ankle fractures with complete biodegradable plates and screws of high molecular weight polylactide. Trans 3 rd world biomaterials congress, Kyoto, Japan, 1988:195.

Gay B, Bucher H. Tierexperimentelle Untersuchungen zur Anwendung von absorbierbaren Osteosyntheseschrauben aus Polydioxanon (PDS). Unfallchirurgie 1985; 88:126-33. (Eng. abstr.) 
O. BÖSTMAN, E. HIRVENSALO, J. MÄKINEN, P. ROKKANEN

Greve H, Holste J. Refixation osteochondraler Fragmente durch resorbierbare Kunststoffstifte. Aktuel Traumatol 1985; 15:145-9. (Eng. abstr.)

Haas H-G. PDS-Splinte zur Frakturbehandlung. Handchirurgie 1986; $18: 295-7$.

Hirvensalo E, Böstman O, Vainionpää S, Törmälä P, Rokkanen P. Biodegradable fixation in chevron osteotomy for hallux valgus. Acta Orthop Scand 1988a; Suppl 227:71.

Hirvensalo E, Böstman O, Vainionpää S, Törmälä P, Rokkanen P. Biodegradable fixation in intraarticular fractures of the elbow joint. Acta Orthop Scand 1988b; Suppl 227:78-9.

Hollinger JO, Battistone GC. Biodegradable bone repair materials: synthetic polymers and ceramics. Clin Orthop 1986; 207 : 290-305.

Howard CB, McKibbin B, Ráliš ZA. The use of Dexon as a replacement for the calcaneal tendon in sheep. J Bone Joint Surg [ Br] 1985; 67$\mathrm{B}: 313-6$.

Miller RA, Brady JM, Cutright DE. Degradation rates of oral resorbable implants (polylactates and polyglycolates): rate modification with changes in PLA/PGA copolymer ratios. J Biomed Mater Res 1977; $11: 711-9$.
Partio EK, Böstman O, Vainionpää S, et al. The treatment of cancellous bone fractures with biodegradable screws. Acta Orthop Scand 1988; Suppl 227:18.

Rokkanen P, Böstman O, Vainionpää S, et al. Biodegradable implants in fracture fixation. Lancet $1985 ; \mathrm{i}: 1422-4$.

Rokkanen P, Böstman O, Hirvensalo E, Vainionpää S, Törmälä P. Three years' audit of biodegradable osteofixation in orthopaedic surgery. Acta Orthop Scand 1988; Suppl 227:18-9.

Rozema FR, Bos RRM, Boering G, et al. Absorbable bone-plates and screws for the fixation of malar fractures. In: de Putter C, de Lange GL, de Groot K, Lee AJC, eds. Implant materials in biofunction. Amsterdam, etc: Elsevier, 1988:251-5.

Törmälă P, Vainionpää S, Pellinen $M$, et al. Totally biodegradable polymeric self-reinforced (SR) rods and screws for fixation of bone fractures. Trans 3rd world biomaterials congress, Kyoto, Japan, 1988:501.

Vert M, Christel P, Chabot F, Leray J. Bioresorbable plastic materials for bone surgery. In: Hastings GW, Ducheyne P, eds. Macromolecular biomaterials. Boca Raton, Florida: CRC Press, 1984:119-41.

Williams DF. Consensus and definitions in biomaterials. In: de Putter $\mathrm{C}$, de Lange GL, de Groot K, Lee AJC, eds. Implant materials in biofunction. Amsterdam, etc: Elsevier, 1988:11-6. 